\title{
How a Mediating Variable Need in the Loyalty Examination?
}

\author{
Bima Andrianto Pambudi ${ }^{1}$, Euis Soliha ${ }^{\circledR}$, Endang Tjahjaningsih ${ }^{3}$ \\ Postgraduate Program of Magister Management, Stikubank University, Semarang, Indonesia ${ }^{1}$ \\ Management Department, Faculty of Economic and Business, Stikubank University, Semarang \\ Indonesia ${ }^{2,3}$
}

\section{Info Article}

History Article:

Received 30 July 2018

Approved 18 September 2018

Published September 2018

Keywords:

Bank Image; Service Quality;

Satisfaction; Loyalty.

\begin{abstract}
The aim of this study was to analyze the effect of bank image and service quality to satisfaction and their impacts on customer loyalty. The object of this research was Bima saving customers at PT. Bank Pembangunan Daerah Jawa Tengah, Klaten Branch. In this study the population used was limited to the customers of the Bima Savings at PT Bank Pembangunan Daerah Jawa Tengah, Klaten Branch. The sample was 97 respondents with the sampling technique of Purposive. The samples were carefully selected so that they were relevant to the study. The results of the research indicate that: bank image has positive significant effect on satisfaction; service quality has positive significant effect on satisfaction; bank image has positive significant effect on loyalty; service quality has positive significant effect on loyalty and satisfaction has positive significant effect on loyalty. The results of mediation effect show that bank image and service quality more effectively influence directly on customer loyalty than through customer satisfaction. Satisfaction is significantly capable as a mediator in the association.
\end{abstract}

\section{Bagaimana Variabel Mediasi dibutuhkan dalam Uji Loyalitas?}

\begin{abstract}
Abstrak
Penelitian ini bertujuan menganalisis pengaruh citra bank, dan kualitas layanan terhadap kepuasan serta dampaknya terhadap loyalitas nasabah. Obyek penelitian adalah nasabah tabungan Bima Pada PT Bank Pembangunan Daerah Jawa Tengah Cabang Klaten. Sampel penelitian sebanyak 97 responden, dengan teknik pengambilan sampel Purposive dimana sampel yang dipilih secara cermat sehingga relevan dengan penelitian. Hasil penelitian menunjukkan bahwa citra bank berpengaruh positif dan signifikan terhadap kepuasan, kualitas layanan berpengaruh positif dan signifikan terhadap kepuasan, citra bank berpengaruh positif dan signifikan terhadap loyalitas, kualitas layanan berpengaruh positif dan signifikan terhadap loyalitas serta kepuasan berpengaruh positif dan signifikan terhadap loyalitas. Hasil efek mediasi menunjukkan bahwa citra bank maupun kualitas layanan lebih efektif berpengaruh secara langsung terhadap loyalitas nasabah dibanding melalui kepuasan nasabah. Kepuasan secara signifikan mampu sebagai mediator dalam hubungan tersebut.
\end{abstract}

JEL Classification: M3, M31

How to Cite: Pambudi, B. A., Soliha, E., \& Tjahjaningsih, E. (2018). How a Mediating Variable Need in the Loyalty Examination?. Jurnal Dinamika Manajemen, 9(2), 179-188. 


\section{INTRODUCTION}

Business competition in the field of banking is very fast; banks compete to be the best by doing various ways to remain a healthy bank by paying attention to all financial ratios, utilizing certain businesssegments, and emphasizing on infrastructures. Having good imagein public will be a consequence of image formation. Harsono (2015) explains that image is defined as an impression obtained in accordance with one's knowledge and experience about something.

Improving service quality is also expected to improve company image because image can be strengthened when customers get high service quality; and it will decrease when the service quality is low. Zeithaml et al. (1996) define service quality as a comparison between consumer expectations and perceptions to the service performance they receive (perception expectations). When the service received or perceived is in accordance with expectations, the service quality is perceived as good and satisfactory. Conversely, when the service received or perceived is not as expceted, the service quality is perceived as is not good and unsatisfactory.

Aydin and Ozer (2004) explain that, in tight competitive conditions, the main thing that must be prioritized is customer satisfaction which will ultimately increase customer loyalty so that the company can survive, compete and control the market share. The research results of Salam et al. (2013) and Sutardjo and Soliha (2014) show that there is a positive and significant effect of image on customer satisfaction, and there is a positive and significant effect of image on customer loyalty. Sumadi and Soliha (2015) show that there is a positive and significant effect of bank image on customer satisfaction,customer satisfaction is significantly capable as a mediator on the effect of bank image on customer loyalty.

Similarly, the results of the research conducted by Yu et al.(2006) and Dewi et al. (2014) show the findings that service quality has a positive effect on customer satisfaction, and satisfaction has a positive effect on loyalty.
The results of the research conducted by Zeithaml et al. (1996) develop a thought on the consequences of consumer behavior resulting from a good service quality. In their research results show that good service quality has an impact on the formation of positive consumer behavior, such as repeat purchase, decreased sensitivity to price and increased service value of services in the eyes of consumers.

The previous studies conducted by (Seth et al., 2004; Yu et al., 2006; Hidayat, 2009; and Dewi et al., 2014) state that service quality has a positive significant effect on loyalty. In contrast, Saputra (2014) found that service quality has positive but not significant effect on loyalty and Aryani and Rosinta (2010) provide research result that service quality has no significant effect on customer loyalty. Likewise, the research of Suratno et al. (2016) and Zameer et al. (2015) state that there is a positive and significant effect of brand image on customer loyalty, but Saputra (2014) shows different result that bank image has negative and significant effect on customer loyalty. Sumadi and Soliha (2015) shows that bank image has no significant effect on customer loyalty.

Bank Pembangunan Daerah Jawa Tengah was established in Semarang as the operational base of Central Java. The purpose of establishing the bank is to manage local finance as a holder of Regional Cash and to help improve the local economy by giving credit to small entrepreneurs. Bank Pembangunan Daerah Jawa Tengah is a Bank owned by the Central Java Provincial Government and the City/ Regency Governments of Central Java. Third party funds consisting of savings, time deposits and current accounts are collected by PT. Bank Pembangunan Daerah Jawa Tengah in 2013 amounting to $25,548,701$ million IDR, in 2014 it accounted for 29,406,355 million IDR and 38,888,224 million IDR in 2015. The growth shows an increase from year to year. Bank Jateng was the object of this research, particularlythe savings customers of Bima, as a product of Bank Jateng specially designed for life investment in the present and future. Similarly, the increase in the amount 
Bima Andrianto Pambudi et al./ The Effect of Company Image and Service Quality on ...

of savings that were collected in 2013 was 8,787,132 million IDR, 9,527,918 million IDR in 2014 and 11,181,897 million IDR in 2015.

Based on the results of the research gap above and against the background proposed, this study has several novelties, there are especially in bank image, service quality and satisfaction also their impacts on customer loyalty.

\section{Hypothesis Development \\ Effect of Bank Image on Satisfaction}

Tran (2015) argues that bank image is a view or perception of a company by people both inside and outside the company. The observers of companies are the customers of the companiesother than shareholders, community, banks and partners. Harsono (2015) explains that image is defined as an impression obtained in accordance with one's knowledge and experience on something. An effective image uses the first three things; establishing product character and value proposals, conveying the character in a different way so as not to be confused with competitor's characters, and providing an emotional power that is nothing more than a mental image. In order to function the image, it must be conveyed through every means of communication available and brand or company contact. Image is very important for service companies and expected to build customer satisfaction (Seth et al., 2004).

Bank image and reputation are considered an important factor in the overall evaluation of an organization (Wu, 2014) because of the strength that lies in the perception and the mind of the customers when hearing the name of the organization. Akbar and Parvez (2009) describes image as a set of beliefs, ideas and impressions a person has on an object. Image is an impression obtained in accordance with one's knowledge and experience on something. People's attitudes and actions towards an object are determined by the image of the object. The research of Malik et al. (2012) and Suratno et al. (2016) show that there is a positive and significant effect of bank image on customer satis- faction. A good bank image will give customers a sense of satisfaction. The higher the image of the bank, the higher the customer satisfaction. Therefore, a company needs to improve its bank image in order to provide customer satisfaction. Thus, the research hypothesis can be formulated as follows:

$\mathrm{H} 1$ : Bank image has positive effect on satisfaction.

\section{Effect of Service Quality on Satisfaction}

Service quality is described as a form of attitude; related but not identical to the satisfaction obtained by comparing expectations with performance (Zeithaml et al., 1996). Attitude, in this case, is an expression of the deepest feeling that indicates whether a person is sympathetic or not sympathetic towards an object; for example, to service brand (Long \& Schiffman, 2010). Zeithaml et al. (2002) define service quality as a comparison between consumer expectations and perceptions when the service is received or perceived as expected. Then, the service quality is perceived as good and satisfactory. Conversely, when the service received or perceived does not meet expectations, the quality of the service is perceived as unfavorable and unsatisfactory.

Akbar and Parvez (2009) explains that satisfaction is one's feeling of pleasure or disappointment that emerges after comparing the performance (outcome) of the product thought with expected performance (or outcome). When the service is below expectations, the customer is not satisfied. Otherwise, when the service meets expectations, the customer is satisfied. Although the service quality is perceived as "perceived by the customer" (Zeithaml et al., 2002) service provider is a person who creates and provides the service. Service provider is an organization's ambassador because it values the balance of quality in service in the minds of customers (Surprenant \& Solomon, 1987). There are several empirical studies that supported that service quality affects satisfaction, as conducted by Yu et al. (2006) and Kurniawati (2014). The 
results show that service quality has positive and significant effect on customer satisfaction. The better the service quality, the more it will give satisfaction to customers (Jahanshahi et al., 2011). Hence, the research hypothesis can be formulated as follows:

$\mathrm{H} 2$ : Service quality has positive effect on satisfaction.

\section{Effect of Bank Image on Loyalty}

Harsono (2015) explains that the image formed is based on impression and experience experienced by someone to something so that it builds a mental attitude and shows the importance of the effect of image on loyalty. This mental attitude is used as a consideration for making decisions because image is considered to represent the totality of one's knowledge of something. Satriyanti (2012) explains that the concept of loyalty leads to behavior rather than to attitudes, and a loyal customer will show his purchasing behavior that can be interpreted as a well-arranged pattern of purchases and in a long time made by the units of decision maker. The results of the studies of Suratno et al. (2016) show that there is a positive and significant effect of bank image on customer loyalty. This shows that by improving the image of the bank it will give a positive impression on the customer and impact on increasing customer loyalty to the company. The higher the image of the bank, the higher the loyalty of the customer. Thus, the hypothesis of this study can be formulated as follows:

H3: Bank image has a positive effect on loyalty.

\section{Effect of Service Quality on Loyalty}

Loyalty and retention are the most important goals for the success of service organizations (Yang \& Peterson, 2004). Satisfaction is an allegiance required for loyalty but not enough by itself to automatically lead to repeat purchases (Hong \& Goo, 2004). According to Zeithaml et al. (1988) loyalty is defined as a combination of intention, advocacy, intention and preference. Singh (2006) states that measu- ring loyalty is used as an indicator of percentage of product purchases, frequency of visits within a certain period, recommendation to family and friends to use the product/ service.

The other opinions concerning the research to measure loyalty are (Long \& Schiffman, 2010) consumers are considered loyal when the consumers have made at least three repeat purchases at the same company, loyalty can be measured by paying attention to the process of using the services of the company where a family always faithfully utilize the services provided by the company, loyalty can be measured from the attitude of consumers to the company, loyalty can be measured from the level of consumer's involvement.

According to Zeithaml et al. (2002) service quality can be defined as to what extent the difference between reality and customer expectation to the service received. Service quality is realized through the fulfillment of customer needs and desires as well as the accuracy of delivery in order to compensate or exceed customer expectations. Rasheed and Abadi (2014) explains that loyalty is seen as a deeply held commitment to buy or support a preferred product or service in the future, even if the effect of the marketing situation and effort has the potential to drive customers.

Good service will make customers happy and potentially remain loyal to the product and company. The results of the research of Yu et al. (2006) provide the findings that service quality positively affects loyalty. In line with the results of the research of Dewi et al. (2014) it shows that service quality has a positive and significant impact on customer loyalty. Poor service or quality will bear the risk of unloyal customers. On the contrary, when service quality is considered or even strengthened, customer loyalty will be more easily obtained. The better the service quality, the more loyal the customers will be to the company. Thus, the research hypothesis can be formulated as follows:

H4: Service quality has a positiveeffect on loyalty. 
Bima Andrianto Pambudi et al./ The Effect of Company Image and Service Quality on ...

\section{Effect of Satisfaction on Loyalty}

The relation of service quality with customer loyalty is also stated by Zeithaml et al. (1996). In their research, it was suggested that service quality significantly affects consumer behavior to be loyal to a service/ product. Of overall activities undertaken by a company, it will finally lead to the value that will be given by the customers about the perceived satisfaction. Customers will not have good attitude towards a service provider compared to other alternatives available without some degree of satisfaction. The higher the satisfaction, the more loyal the customers to the company. In the studies conducted by (Aydin \& Ozer, 2005; Dewi et al., 2014) the results show that customer satisfaction has a positive and significant effect on customer loyalty. Thus, this research hypothesis can be formulated as follows:

H5: Customer satisfaction has a positive effect on loyalty.

The research model can be shown in Figure 1.

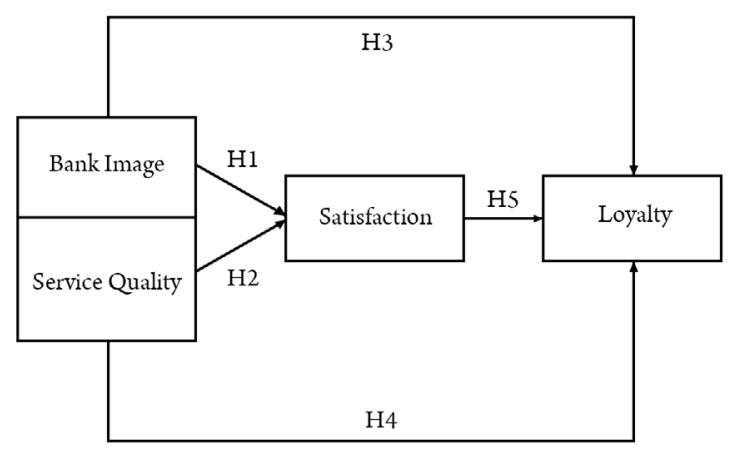

Figure 1. Research Model

\section{METHOD}

\section{Population and Sample}

The population used was limited only to the customers of Bima Savings at PT Bank Pembangunan Daerah Jawa Tengah, Klaten Branch, with the sample of 97 respondents. The sampling technique used in this research was Purposive sampling (purposed sample).

\section{Data Collection Method}

The data collection method in this study was survey method using the questionnaires delivered directly to the respondents. The scale used in the preparation of the questionnaires was the ordinal scale or often called the Likert scale, which is a scale that consists of 7 scales.

\section{RESULT AND DISCUSSION}

\section{Instrument Test \\ Validity Test}

For the validity test of the variablesof bank image, service quality, satisfaction and customer loyalty. To test the validity of each variable, it can be seen from the figure of $\mathrm{KMO}$ which is compared with the standard number of 0.5 , so it is feasibleto be tested to the next test because the sample is considered to be enough. To test each item, it was conducted by looking at the highest loading value. The validity test was conducted to the independent variables $(\mathrm{X})$ and dependent variables $(\mathrm{Y})$ above because the matrixcomponent figure $>$ loading figure. Then, all instruments (question/ indicatoritems) were declared valid, so they are feasible to be used as the research instruments.

\section{Reliability Test}

Table 1. Reliability Test

\begin{tabular}{clccc}
\hline No & \multicolumn{1}{c}{ Variable } & $\begin{array}{c}\text { Alpha } \\
\text { Cronbach }\end{array}$ & $\begin{array}{c}\text { Rate of } \\
\text { Thumb }\end{array}$ & Criteria \\
\hline 1 & $\begin{array}{l}\text { Bank Image } \\
\left(\mathrm{X}_{1}\right)\end{array}$ & .784 & .7 & Reliable \\
2 & $\begin{array}{l}\text { Service Quality } \\
\left(\mathrm{X}_{2}\right)\end{array}$ & .892 & .7 & Reliable \\
4 & $\begin{array}{l}\text { Satisfaction } \\
\left(\mathrm{Y}_{1}\right)\end{array}$ & .897 & .7 & Reliable \\
5 & $\begin{array}{l}\text { Customer } \\
\text { Loyalty }\left(\mathrm{Y}_{2}\right)\end{array}$ & .832 & .7 & Reliable \\
\hline
\end{tabular}

Reliability test result (Table 1) was used to measure the extent to which the variables provide reliable/ consistent results. The reliability testing used Cronbach alpha formula. In the reliability test, bank image, service quality, 
satisfaction and customer loyalty are reliable/ consistent and worthy of use for further hypothesis testing.

\section{Regression Results}

Based on the results of the statistics data processing using SPSS, the summary of the output is showed in Table 2 .

\section{Model Test}

Model 1: Bank Image and Service Quality have an Effect on Satisfaction

\section{Determination Coefficient Test (Adjusted R Square)}

Determination coefficient is essentially to measure the ability of model in independent variable in explaining the variation of dependent variable. The figure of determination coefficient (Adjusted R Square) is of 0.243 meaning that the variables of bank image and service quality have the contribution of $24.3 \%$ to satisfaction, while the rest is: $(100 \%-24.3 \%)=75.74 \%$. It is in- fluenced by the factors out of the research model. The result shows that in model 1 , the value of determination coefficient obtained is small $(<50 \%)$, so model 1 can be said fair.

\section{F-Test}

F-value is 16.447 with a significance level of 0.000 is smaller than $5 \%$ or 0.05 , so the model meets the requirement of Goodness of Fit. Then, it can be used to explain the effect of bank image and service quality on satisfaction. Thus, the bank image and service quality simultaneously have a significant effect on satisfaction.

\section{Hypothesis Testing}

Multiple linear regression equation was used to find out the effect of the independent variablesof bank image and service quality on satisfaction. The equation of the multiple linear line (seen from the standard coefficient beta) obtained is as follows:

$$
Y_{1}=0.274 X_{1}+0.350 X_{2}
$$

Table 2. Output of Research Results

\begin{tabular}{|c|c|c|c|c|c|c|c|c|}
\hline \multirow{2}{*}{ Model } & \multirow{2}{*}{ Variable } & \multirow{2}{*}{$\frac{\text { KD }}{\left(\operatorname{Adj} R^{2}\right)}$} & \multicolumn{2}{|c|}{ Anova } & \multicolumn{3}{|c|}{ Regression } & \multirow[t]{2}{*}{ Remark } \\
\hline & & & $\mathbf{F}$ & Sig. & Beta & $\mathbf{t}$ & Sig. & \\
\hline \multirow[t]{3}{*}{ I } & $\begin{array}{l}\mathrm{Y} 1=\alpha 1+\beta 1 \mathrm{X} 1+ \\
\beta 2 \mathrm{X} 2+\mathrm{e}\end{array}$ & .243 & 16.447 & .000 & & & & \\
\hline & $\begin{array}{l}\text { Effect of Com- } \\
\text { pany Image on } \\
\text { Satisfaction }\end{array}$ & & & & .274 & 2.925 & .004 & $\mathrm{H} 1$ : supported \\
\hline & $\begin{array}{l}\text { Effect of Service } \\
\text { Quality on Satis- } \\
\text { faction }\end{array}$ & & & & .350 & 3.738 & .000 & H2: supported \\
\hline \multirow[t]{7}{*}{ II } & $\begin{array}{l}\mathrm{Y} 2=\alpha 2+\beta 3 \mathrm{X} 1+ \\
\beta 4 \mathrm{X} 2+\beta 5 \mathrm{Y} 1+\mathrm{e}\end{array}$ & .506 & 33.807 & .000 & & & & \\
\hline & $\begin{array}{l}\text { Effect of Com- } \\
\text { pany Image on }\end{array}$ & & & & .341 & 4.317 & .000 & H3: supported \\
\hline & Loyalty & & & & .385 & 4.742 & .000 & H4: supported \\
\hline & Effect of Ser- & & & & & & & H5: supported \\
\hline & vice Quality on & & & & .213 & 2.554 & .012 & \\
\hline & Loyalty & & & & & & & \\
\hline & $\begin{array}{l}\text { Effect of Satisfac- } \\
\text { tion on Loyalty }\end{array}$ & & & & & & & \\
\hline
\end{tabular}


From the equation, it shows that bank image has positive and significant effect on satisfaction with the regression coefficient of 0.274 . Then, service quality has positive effect on satisfaction with the regression coefficient of 0.350 . Service quality has a greater effect on satisfaction than that of bank image on satisfaction.

\section{H1: Bank Image has a Positive Effect on Custo- mer Satisfaction}

The result of the statistical data processing obtained the sig value of $0.004<$ the significance level $\alpha=5 \%$ (0.05).Itmeans that partially (individually) there is positive and significant effect between bank image on satisfaction with the coefficient standard beta of 0.274 . Thus, the first hypothesis that bank image has a positive effect on the satisfaction of the customers of bank is accepted. It means that the higher the image of the bank, the higher the customer satisfaction.

\section{H2: Service Quality has a Positive Effect on Cus- tomer Satisfaction}

The results of processing statistical data obtained the sig value of $0.000<$ the significance level $\alpha=5 \%(0.05)$ between service quality $\left(\mathrm{X}_{2}\right.$ and satisfaction $\left(\mathrm{Y}_{1)}\right.$. It means that partially (individually) there is a positive and significant effect between service quality $\left(\mathrm{X}_{2}\right)$ and satisfaction $\left(\mathrm{Y}_{1}\right)$ with the standardized coefficient beta of 0.350 (b2). Thus, the second hypothesisstating that service quality has a positive effect on the satisfaction of the customers of bank is accepted It means that the higher the service quality, the higher the customer satisfaction.

\section{Model 2: Effect of Bank Image, Service Quality and Satisfaction on Customer Loyalty Determination Coefficient Test (Adjusted R Square)}

Determination coefficient essentially measures the ability of the model in independent variable $(\mathrm{X})$ in explaining the variation of dependent variable $(Y)$. From the regression test results, the determination coefficient (Adjusted $R$ Square) obtained is 0.506 . It means that the variables of bank image, service quality and satisfaction have contribution to Customer Loyalty of $50.6 \%$. The rest $(100 \%-50.6 \%)=49.4 \%$ is influenced by the factors out of the research model. The results indicate that, in model 2 , the value of determination coefficient obtained is quite large (> 50\%), so model 2 can be identified quite good.

\section{F-Test}

The value of $\mathrm{F}$ is 33.807 with a significance level of 0.000 which is smaller than $5 \%$ or 0.05 . Then, the model meets the requirement of Goodness of Fit, so it can be used to explain the effect of bank image, service quality and satisfaction on customer loyalty. Thus, bank image, service quality and satisfaction simultaneously/ collectively have a significant effect on customer loyalty.

\section{Hypothesis Testing}

Multiple linear regression equation was used to determine the effect of several independent variables of bank image, service quality, andsatisfaction on customer loyalty. The results of the data processing for the second model show the regression equation as follows:

$$
\mathrm{Y}_{2}=0.341 \mathrm{X}_{1}+0.385 \mathrm{X}_{2}+0.213 \mathrm{Y}_{1}
$$

From the regression equation above, it shows that service quality has the greatest effect on customer loyalty with the regression coefficient of 0.385 . Then, bank image also has a positive effect on customer loyalty with the regression coefficient of 0.341 and satisfaction has the regression coefficient of 0.213 . Service quality has a greater effect on satisfaction than that of bank image and satisfaction on satisfaction.

\section{H3: Bank Image has a Positive Effect on Custo- mer Loyalty}

The results of the statistical data processing show the probability value of $0.000<$ significance level $\alpha=5 \%$ (0.05). It means that partially and significantly there is a positive effect of bank image on customer loyalty with a standard 
coefficient beta of 0.341 . Thus, the third hypothesis which states that bank image positively affects the loyalty of the customers of bank is accepted. It means that the higher the image of the bank, the higher the loyalty of the customer.

\section{H4: Service Quality has a Positive Effect on Cus- tomer Loyalty}

The results of the statistical data processing show the probability value of $0.000<$ significance level $\alpha=5 \%$ (0.05) between service quality and customer loyalty. It means that partially there is positive and significant effect of service quality on customer loyalty with a standard coefficient beta of 0.385 . Thus, the fourth hypothesis stating that service quality positively influences the loyalty of the bank is accepted. It means that the higher the service quality, the higher the customer loyalty.

\section{H5: Customer Satisfaction has a Positive Effect on Customer Loyalty}

The results of the statistical data processing show the probability value of $0.012<$ significance level $\alpha=5 \%$ (0.05) It means that partially there is positive and significant effect of satisfaction on customer loyalty with a standard coefficient beta of 0.213 . Thus, the fifth hypothesis stating that satisfaction positively influences the loyalty of the customers at bank is accepted. It means that the higher the bank image, the higher the customer loyalty. It means that the higher the customer satisfaction, the higher the customer loyalty.

Test of the Mediation Effect of Satisfaction on the Effect of Bank Image on Customer Loyalty

Table 3. Sobel Test Result 1

\begin{tabular}{lcc}
\hline \multicolumn{1}{c}{ Mediation Effect } & Value & Sig \\
\hline $\begin{array}{l}\text { Satisfaction on the effect of } \\
\text { Bank Image on customer }\end{array}$ & .1450 & .0043 \\
loyalty & & \\
\hline
\end{tabular}

To test the effect of the mediation variables, Sobel Test was used (Table 3). Sobel test is a test to determine whether the association through a mediation variable is significantly capable as a mediator in the association. From the existing data of the test results, the effect of the mediation variable can be explained in the following table of Sobeltest results:

The output of SPSS on Sobel and Bootstrap tests, it shows that there is indirect effect of bank image on loyalty with satisfaction as mediation with the value of 0.1450 and the level of significance of $0.0043<0.005$. It means that satisfaction is significantly as a mediator in that relationship.

Test of the Mediation Effect of Satisfaction on the Effect of Service Quality on Customer Loyalty

Sobel test is a test to determine whether the association through a mediation variable is significantly capable as a mediator in the association. From the existing data of the test results, the effect of the mediation variable satisfaction can be explained in the following table of Sobel test results:

Table 4. Sobel Test Result 2

\begin{tabular}{lcc}
\hline \multicolumn{1}{c}{ Mediation Effect } & Value & Sig \\
\hline $\begin{array}{l}\text { Satisfaction on the effect of } \\
\text { service quality on customer }\end{array}$ & .1450 & .0044 \\
loyalty & & \\
\hline
\end{tabular}

Based on Table 4, of the output of SPSS on Sobel and Bootstrap tests, it shows that there is an indirect effect of service quality on loyalty with satisfaction as mediation with the value of 0.1955 and the level of significance of $0.0044<$ 0.005 . It means that satisfaction is significantly as a mediator in that relationship.

\section{CONCLUSIONAND RECOMMENDATION}

Based on the research results in the previous chapter, some conclusions can be drawn as follows: Bank image has a positive and significant effect on customer satisfaction. The better the image of the bank,the higher the customer satisfaction. Service quality has a positive and significant effect on customer satisfaction. The 
Bima Andrianto Pambudi et al./ The Effect of Company Image and Service Quality on ...

better the service quality, the higher the customer satisfaction.

Bank image has a positive and significant effect on customer loyalty. The better the image of the bank,the higher the customer loyalty. Service quality has a positive and significant effect on customer loyalty. The better the service quality, the higher the customer loyalty. Customer satisfaction has a positive and significant effect on customer loyalty. The higher the customer satisfaction, the higher the customer loyalty.

The results of the first mediation effect show that satisfaction is significantly capable as a mediator on the effect of service bank image on customer loyalty. The results of the second mediation effect indicate that satisfaction is significantly capable as a mediator on the effect of service quality on customer loyalty.

Bank image will be achieved optimally when the company focuses on its core business to reflect its core competencies. Customers are satisfied with the services provided by the bank so that it will create loyalty that causes the bank to remain exist. Satisfaction is a full-time evaluation in which the alternatives are at least able to deliver the same results or to exceed customer's expectations. This indicates that although customers are satisfied with the banking products, it needs the development and facilities of other banking products. Customer's loyalty is a favorable attitude towards a brand that is represented in a consistent purchase of the brand.

The factors that affect the satisfaction and loyalty of bank customers are not only limited to the variables of service quality and bank image, but it can also be developed with the variables of customer value, trust, or marketing relationships. It will surely be the information for future research to analyze other factors that affect customer satisfaction and loyalty other than the independent variables above.

\section{REFERENCES}

Abd-El-Salam, E. M., Shawky, A. Y., \& El-Nahas, T. (2013). The Impact of Corporate Image and Reputation on Service Quality, Customer
Satisfaction and Customer Loyalty: Testing the Mediating Role. Case Analysis in an International Service Company. The Business w Management Review, 3(2), 177-196.

Akbar, M. M., \& Parvez, N. (2009). Impact of Service Quality, Trust and Customer Satisfaction on Customers Loyalty. ABAC Journal, 29(1), 24-38.

Anderson, E. W., \& Fornell, C. 1994. A Customer Satisfaction Research Prospectus, in Service Quality: New Directions in Theory and Practice, eds. Thousand Oaks, California: Sage Publications, 241-268.

Anggraeni, L. R. (2013). Pengaruh Kualitas Pelayanan terhadap Kepuasan dan Loyalitas Nasabah (Studi pada Nasabah PT. Bank Rakyat Indonesia (Persero), Tbk Unit Mlarak Cabang Ponorogo). Jurnal Ilmiah Mahasiswa FEB, 2(2), 29-41.

Aryani, D \& Rosinta, F. (2010). Pengaruh Kualitas Layanan terhadap Kepuasan Pelanggan dalam Membentuk Loyalitas Pelanggan. Jurnal Ilmu Administrasi dan Organisasi, 17(2), 114-126.

Aydin, S., Özer, G., \& Arasil, Ö. (2005). Customer Loyalty and the Effect of Switching Costs as a Moderator Variable: a Case in the Turkish Mobile Phone Market. Marketing Intelligence \& Planning, 23(1), 89-103.

Belás, J. G. (2014). Reasons for Satisfaction and Dissatisfaction of Bank Customers. Study from Slovakia and the Czech Republic. International Journal of Entrepreneurial Knowledge, 2(14), 4-13.

Dewi, R. K., Yasa, N. N. K., \& Sukaatmadja, I. P. G. (2014). Pengaruh Kualitas Pelayanan terhadap Kepuasan dan Loyalitas Nasabah PT BPR HOKI DI Kabupaten Tabanan. E-Jurnal Ekonomi dan Bisnis Universitas Udayana, 3(5), 257-275.

Harsono, S. (2015). The Institution Image and Trust and Their Effect on the Positive Word of Mouth. International Research Journal of Business Studies, 7(1).

Hong, S. C., \& Goo, Y. J. (2004). A Causal Model of Customer Loyalty in Professional Service Firms: an Empirical Study. International Journal of Management, 21(4), 531-540.

Jahanshahi, A. A., Gashti, M. A. H., Mirdamadi, S. A., Nawaser, K., \& Khaksar, S. M. S. (2011). Study the Effects of Customer Service and 
Product Quality on Customer Satisfaction and Loyalty. International Journal of Humanities and Social Science, 1(7), 253-260.

Kurniawati, D. (2014). Pengaruh Citra Merek dan Kualitas Produk terhadap Kepuasan dan Loyalitas Pelanggan (Studi pada Pelanggan KFC Cabang Kawi Malang). Jurnal Administrasi Bisnis, 14(2), 1-9.

Long, M. M., \& Schiffman, L. G. (2010). Consumption Values and Relationships: Segmenting the Market for Frequency Programs. Journal of Consumer Marketing, 17(3), 214-232.

Malik, M. E., Ghafoor, M. M., \& Hafiz, K. I. (2012). Impact of Brand Image, Service Quality and Price on Customer Satisfaction in Pakistan Telecommunication Sector. International Journal of Business and Social Science, 3(23), 123-129.

Rasheed, F. A., \& Abadi, M. F. (2014). Impact of Service Quality, Trust and Perceived Value on Customer Loyalty in Malaysia Services Industries. Procedia-Social and Behavioral Sciences, 164, 298-304.

Saputra, F. I. (2013). Kualitas Layanan, Citra dan Pengaruhnya terhadap Loyalitas melalui Kepuasan Pelanggan (Studi pada PT Bank BNI 46 Sentra Kredit Kecil Surabaya). Jurnal Aplikasi Manajemen, 11(3), 445-457.

Satriyanti, E. O. (2012). Pengaruh Kualitas Layanan, Kepuasan Nasabah dan Citra Bank terhadap Loyalitas Nasabah Bank Muamalat di Surabaya. Journal of Business \& Banking, 2(2), 171-184.

Schiffman, L, G., \& Kanuk, L. (2010). Customer Behaviour. Englewood Cliffs, New Jersey: Prentice Hall.

Seth, N., Deshmukh, S. G., \& Vrat, P. (2005). Service Quality Models: a Review. International Journal of Quality \& Reliability Management, 22(9), 913-949.

Singh, H. (2006). The Importance of Customer Satisfaction in Relation to Customer Loyalty and Retention. Academy of Marketing Science, 60, 193-225.

Sumadi, S., \& Soliha, E. (2015). The Effect of Bank Image and Trust on Loyality Mediated by Customer Satisfaction. Jurnal Dinamika Manajemen, 6(2), 121-132.

Suratno, S., Fathoni, A., \& Haryono, A. T. (2016). Pengaruh Citra Perusahaan dan Kualitas
Pelayanan terhadap Loyalitas Pelanggan dengan Kepuasan Pelanggan sebagai Variabel Intervening pada PT Pelabuhan Indonesia III Semarang. Journal of Management, 2(2), 1-16.

Surprenant, C. F., \& Solomon, M. R. (1987). Predictability and Personalization in the Service Encounter. The Journal of Marketing, 51(1), 86-96.

Sutardjo, F. X. S. W., \& Soliha, E. (2014). Pengaruh Persepsi Harga, Citra Perusahaan dan Citra Merek terhadap Kepuasan dan Loyalitas Pelanggan pada Apotek "Dela" di Semarang. Proceeding. Fakultas Ekonomi, Unisbank Semarang.

Tran, M. A., Nguyen, B., Melewar, T. C., \& Bodoh, J. (2015). Exploring the Corporate Image Formation Process. Qualitative Market Research: an International Journal, 18(1), 86-114.

$\mathrm{Wu}$, H. C. (2014). The Effects of Customer Satisfaction, Perceived Value, Corporate Image and Service Quality on Behavioral Intentions in Gaming Establishments. Asia Pacific Journal of Marketing and Logistics, 26(4), 540-565.

Yang, Z., \& Peterson, R. T. (2004). Customer Perceived Value, Satisfaction and Loyalty: the Role of Switching Costs. Psychology \& Marketing, 21(10), 799-822.

Yu, H-C, Chang H-C., \& Huang, G-L. (2006). A Study of Service Quality, Customer Satisfaction and Loyalty in Taiwanese Leisure Industry. The Journal of America academy of Business, Cambridge, 9(1), 126-132.

Zameer, H., Tara, A., Kausar, U., \& Mohsin, A. (2015). Impact of Service Quality, Corporate Image and Customer Satisfaction towards Customers' Perceived Value in the Banking Sector in Pakistan. International Journal of Bank Marketing, 33(4), 442-456.

Zeithaml, V. A., Berry, L. L., \& Parasuraman, A. (1988). Communication and Control Processes in the Delivery of Service Quality. The Journal of Marketing, 52(1), 35-48.

Zeithaml, V. A., \& Bitner, M. J. (1996). Service Marketing. New York: Mc.Graw-Hill.

Zeithaml, V. A., Parasuraman, A., \& Malhotra, A. (2002). Service Quality Delivery through Web Sites: a Critical Review of Extant Knowledge. Journal of the Academy of Marketing Science, 30(4), 362-375. 